\title{
MSH2 Loss of Nuclear Expression
}

National Cancer Institute

\section{Source}

National Cancer Institute. MSH2 Loss of Nuclear Expression. NCI Thesaurus. Code

C160415.

An indication that expression of MSH2 was not detected in the nuclei of cells in a sample. 